\title{
Adenovirus type 5 community-acquired pneumonia in an immunocompetent patient
}

\author{
Katsunori Masaki, ${ }^{\oplus 1,2}$ Takanori Asakura, ${ }_{1}^{1}$ Kaori Sakurai, ${ }^{1,2}$ Kiyofumi Ohkusu ${ }^{3}$
}

'Division of Pulmonary

Medicine, Department of Medicine, Keio University School of Medicine, Tokyo, Japan

${ }^{2}$ Department of Internal Medicine, Saiseikai Utsunomiya Hospital, Utsunomiya, Tochigi, Japan

${ }^{3}$ Department of Microbiology, Tokyo Medical University, Tokyo, Japan

\section{Correspondence to Dr Katsunori Masaki, masaki@keiomed.com}

Accepted 26 March 2019
Check for updates

(C) BMJ Publishing Group Limited 2019. No commercial re-use. See rights and permissions. Published by BMJ.

To cite: Masaki K, Asakura T, Sakurai K, et al. BMJ Case Rep 2019;12:e228914. doi:10.1136/bcr-2018228914

\section{DESCRIPTION}

A previously healthy 55 -year-old Japanese woman was admitted to our hospital with a 5-day history of cough, dyspnoea and high fever. She had two budgerigar parrots, a sparrow and a dog. She had been administered levofloxacin $(500 \mathrm{mg} /$ day $)$ 2 days before admission. She had a grandson who had a cold 6 days before her admission. Her vital signs included a body temperature of $37.8^{\circ} \mathrm{C}$, pulse rate of 72 beats/min, respiratory rate of 20 breaths/min, blood pressure of $120 / 74 \mathrm{~mm} \mathrm{Hg}$ and percutaneous oxygen saturation of $92 \%$ despite administration of $6 \mathrm{~L} / \mathrm{min}$ oxygen via a reservoir mask. Chest examination revealed bilateral wheezing and rhonchi but no crackles. Laboratory tests showed an elevated C-reactive protein $(3.87 \mathrm{mg} / \mathrm{dL}$; normal range $<0.35 \mathrm{mg} / \mathrm{dL})$ with a normal white cell count $\left(4.76 \times 10^{9} / \mathrm{L}\right)$. Chest CT demonstrated bilateral ground-glass attenuation with peribronchial thickening (figure 1). Sputum Gram-stain and culture were negative for any pathogens. Legionella and pneumococcal urinary antigen tests, a rapid influenza diagnostic test using a nasopharyngeal swab and a serum anti-HIV antibody test were also negative. Ceftriaxone $(2000 \mathrm{mg} /$ day $)$ and minocycline $(200 \mathrm{mg} /$ day $)$ were administered for typical

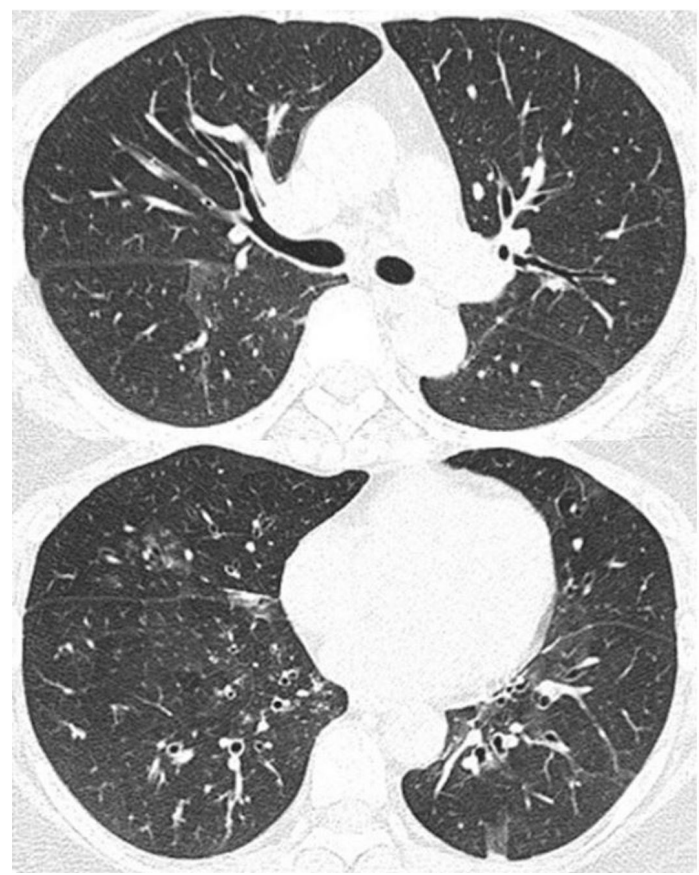

Figure 1 Chest CT on admission demonstrated bilateral ground-glass attenuation and small nodular shadows with peribronchial thickening. and atypical pathogens coverage, respectively. A multiplex, real-time reverse transcriptase PCR (RT-PCR) assay of her sputum was negative for major atypical pathogens known to cause community-acquired pneumonia (CAP). These atypical pathogens included Chlamydophila spp, Mycoplasma pneumoniae, Legionella pneumophila and Coxiella burnetii. However, the 1004 bp fragment of the hexon gene was amplified by PCR, ${ }^{1}$ and the DNA sequence shared homology with adenovirus type 5, searched by BLAST. This was confirmed using a serum neutralisation test, which was also positive for adenovirus type 5. Therefore, the patient was diagnosed with adenovirus type 5 CAP. Subsequently, we discontinued all antimicrobial treatments and transitioned to careful observation as the patient gradually recovered after 1 week of supportive care.

Viral pathogens such as influenza virus, adenovirus and rhinovirus are common causes of atypical CAP. ${ }^{2}$ Although the risk of adenovirus infections of the lower respiratory tract is the greatest in children, ${ }^{3}$ adenovirus is a common pathogen causing acute respiratory infections in older adults as well. ${ }^{4} \mathrm{We}$, therefore, postulate that our patient may have been infected from contact with her sick grandson because adenovirus type 5 is mainly associated with respiratory tract infections in children. ${ }^{5}$ The severity and epidemiology of human adenovirus infections are influenced by

\section{Patient's perspective}

I thought that my difficulty breathing was caused by bronchitis or pneumonia and my symptoms were very similar to those experience by my grandson. My doctors suspected that the pathogens causing my pneumonia came from our family's pet birds. Eventually, my hypothesis might be true!

\section{Learning points}

- Physicians should consider viruses as causative pathogens in patients with atypical communityacquired pneumonia.

- When a physician suspects atypical pneumonia based on patients' reported history or chest imaging, molecular techniques such as realtime reverse transcriptase PCR are useful for diagnosis of atypical pathogens such as adenovirus. 
adenovirus species and type. In children, the most frequent types are human adenovirus types 1,2 and 5, and the CAP that these cause have better prognosis compared with the possibly fatal CAP caused by the highly virulent types 4,7 and 55. ${ }^{5}$ Recently, several rapid molecular tests for viral pathogen detection have become available, which may aid in timely diagnosis and treatment. ${ }^{6}$ Early administration of cidofovir could be an important treatment strategy in cases of severe CAP caused by adenovirus; however, in our case, the patient's symptoms improved with supportive care alone.

Acknowledgements We are deeply grateful to Ichiro Nakachi, Tomoki Matsuo, Daisuke Arai, Hidenori Takanashi, Atsushi Chiyotani and Shigehiro Hagiwara for their assistance.

Contributors KM, TA and KS wrote the article. KO examined RT-PCR assay.

Funding The authors have not declared a specific grant for this research from any funding agency in the public, commercial or not-for-profit sectors.
Competing interests None declared.

Patient consent for publication Not required.

Provenance and peer review Not commissioned; externally peer reviewed.

\section{REFERENCES}

1 Ishiko H, Shimada Y, Konno T, et al. Novel human adenovirus causing nosocomial epidemic keratoconjunctivitis. J Clin Microbiol 2008;46:2002-8.

2 Jain S, Self WH, Wunderink RG, et al. Community-acquired pneumonia requiring hospitalization among U.S. Adults. N Engl J Med 2015;373:415-27.

3 Chau SK, Lee SL, Peiris MJ, et al. Adenovirus respiratory infection in hospitalized children in Hong Kong: serotype-clinical syndrome association and risk factors for lower respiratory tract infection. Eur J Pediatr 2014;173:291-301.

4 Shi T, Arnott A, Semogas I, et al. The etiological role of common respiratory viruses in acute respiratory infections in older adults: a systematic review and meta-analysis. J Infect Dis 2019:jiy662.

5 Scott MK, Chommanard C, Lu X, et al. Human adenovirus associated with severe respiratory infection, Oregon, USA, 2013-2014. Emerg Infect Dis 2016;22:1044-51.

6 Vos LM, Bruning AHL, Reitsma JB, et al. Rapid molecular tests for influenza, respiratory syncytial virus, and other respiratory viruses: a systematic review of diagnostic accuracy and clinical impact studies. Clin Infect Dis 2019.

Copyright 2019 BMJ Publishing Group. All rights reserved. For permission to reuse any of this content visit

https://www.bmj.com/company/products-services/rights-and-licensing/permissions/

BMJ Case Report Fellows may re-use this article for personal use and teaching without any further permission.

Become a Fellow of BMJ Case Reports today and you can:

- Submit as many cases as you like

- Enjoy fast sympathetic peer review and rapid publication of accepted articles

Access all the published articles

Re-use any of the published material for personal use and teaching without further permission

For information on Institutional Fellowships contact consortiasales@bmjgroup.com

Visit casereports.bmj.com for more articles like this and to become a Fellow 